\title{
Influence of retirement on health conditions and quality of life
}

\section{Influência da aposentadoria nas condições de saúde e qualidade de vida}

\section{Pollyanna Natalia Micali ${ }^{1}$ \\ Raiana Lídice Mór Fukushima² \\ Elisôngela Gisele do Carmo ${ }^{3}$ \\ José Luiz Riani Costa ${ }^{4}$ \\ Jamile Sanches Codogno ${ }^{5}$}

Endereço para Correspondência:

Pollyanna Natalia Micali

Avenida 44-A, 995, apto-1, Vila Nova

13.506-610 - Rio Claro, SP [Brasil]

pollymicali@gmail.com

\footnotetext{
1 Instituto de Biociências, Universidade Estadual Paulista UNESP. Rio Claro, SP - Brasil.

ORCID: https://orcid.org/0000-0003-3294-9045

2 Instituto de Biociências, Universidade Estadual Paulista UNESP. Rio Claro, SP - Brasil.

ORCID: https://orcid.org/0000-0002-8791-3851

3 Instituto de Biociências, Universidade Estadual Paulista UNESP. Rio Claro, SP - Brasil.

ORCID: https://orcid.org/0000-0001-9567-1883

4 Instituto de Biociências, Universidade Estadual Paulista UNESP. Rio Claro, SP - Brasil.

ORCID: https://orcid.org/0000-0002-9999-1080

5 Faculdade de Ciências e Tecnologia, Universidade Estadual Paulista - UNESP. Presidente Prudente, SP - Brasil. ORCID: https://orcid.org/0000-0003-9375
}

\begin{abstract}
Introduction: Life expectancy is an important variable for retirement planning. The pension system and the importance of this period have lately been the focus of studies in Brazil. Objective: To evaluate the health conditions and quality of life (QoL) of retirees. Methods: Data collection was performed using the 36-item Short-Form Survey (SF-36), the Brazilian Economic Classification Criteria and a structured questionnaire. We verified the absence of normal data through the Shapiro-Wilk test, and then applied the Mann-Whitney $U$ test in order to compare the groups (retirees who worked and those who did not). The significance level for the statistical tests was 5\%. Results: Among the 205 retirees, we observed that the most prevalent diseases were hypertension $(50.3 \%)$ and depression $(37.0 \%)$. In addition, retirees who continued working after retirement had better health conditions and QoL. Conclusion: It is suggested that retirement planning may be an important alternative to minimize the development of psychosocial diseases and their aggravating factors.
\end{abstract}

Keywords: Retirement. Behavioral medicine. Quality of life.

\section{Resumo}

Introdução: A expectativa de vida é uma variável essencial para o planejamento previdenciário. O sistema previdenciário e a importância desse período têm sido, ultimamente, foco de estudos no Brasil. Objetivo: Avaliar as condições de saúde e qualidade de vida (QV) dos aposentados. Métodos: Para a coleta de dados, aplicou-se o Questionário Genérico de Qualidade de Vida (SF-36), o questionário de Classificação Social Brasileira e um questionário estruturado. A partir do teste de ShapiroWilk, verificou-se a ausência de normalidade dos dados. Usou-se o teste U de Mann-Whitney para comparar os grupos (aposentados que trabalhavam e os que não trabalhavam), considerou-se nível de significância de $\mathrm{p}<0,05$ para todas as análises. Resultados: Nos 205 aposentados, as doenças mais prevalentes foram hipertensão $(50,3 \%)$ e depressão $(37,0 \%)$. Além disso, os aposentados que trabalhavam após a aposentadoria apresentaram melhores condições de saúde e QV. Conclusão: Sugere-se que o planejamento da aposentadoria é uma importante alternativa para minimizar o desenvolvimento de doenças psicossociais e seus agravantes.

Descritores: Aposentadoria. Medicina do comportamento. Qualidade de vida. 


\section{Introduction}

According to the Brazilian Institute of Geography and Statistics (Instituto Brasileiro de Geografia e Estatística, IBGE), Brazil has a population of approximately 26 million elderly people ( $\geq 60$ years old), and it is expected to reach 32 million by $2020^{1,2}$. The extension of life expectancy was accompanied by substantial health enhancements, such as the generalization of health and sanitation services and immunization, leading to a reduction in mortality rates $^{3}$. Scientific and technological expansion and greater access to information and primary health are additional contributing factors to that extension $^{1,2}$. Life expectancy is an important variable in retirement planning.

Retirement may be a demanding period, filled with multiple challenges. These challenges may include difficulties in coping with adverse events, which may arise from an excessive focus on losses and deprivation regarding work-related activities, status, relationships and professional recognition, among others ${ }^{4}$. Free time may no longer be seen as an opportunity for new discoveries and learning and actually reduce the coping capacity for stressors characteristic of the retirement period ${ }^{4}$. Retirement may have consequences on physical and mental health, contributing to physical inactivity ${ }^{5}$. Additionally, the number of daily hours spent in a seated position or other sedentary behaviors are strongly associated with an increased risk for Chronic Non-communicable Diseases $(\mathrm{NCDs})^{5}$. Thus, retirement planning has lately been the focus of studies in Brazil ${ }^{6,7}$. Issues that are associated with retirement, health conditions and quality of life (QoL) are still insufficiently discussed in the Brazilian literature and, consequently, considered a challenge for health care in Brazil ${ }^{8}$.

Rethinking attitudes and behaviors (i.e. healthy habits) is one of the steps to achieving a natural retirement ${ }^{8}$. Therefore, we aimed to evaluate health conditions and QoL of retirees in the city of Rio Claro, Sao Paulo. The hypoth- esis of the present study was that retirees who continue working have higher scores on health conditions and QoL perceptions than the retirees who do not.

\section{Methods}

In the period of 2007-2008, a stratified random sampling procedure was used to select a representative sample of adults aged 20 years and older, residents in the city of Rio Claro. The sample resulted in 1,588 participants ${ }^{9,10,11}$. This study, which was conducted in 2014-2015, was the follow-up stage of the aforementioned study. Thus, it had a cross-sectional design and involved a population sample of adults aged 26 years and older. From the initial sample of 1,588 participants in 2007-2008, 693 were contacted and successfully interviewed in 2014-2015. The sample loss was due to change of address, making contact with the subjects impossible $(\mathrm{n}=$ $342)$; refusal to participate $(\mathrm{n}=144)$; death $(\mathrm{n}=$ $81)$ and other reasons $(n=126)$.

\section{Questionnaires}

Three questionnaires were used for data collection:

1) A sociodemographic questionnaire that registered year of birth / age; sex; amount of schooling (none / elementary I / elementary II / high school / higher education); whether subject continued working after retirement (yes / no) and number and types of diseases after retirement.

2) The Brazilian Economic Classification Criteria (CCEB), which has been widely used as a socioeconomic stratification tool. The survey attributed points to data that included household possessions (per purchasing power), each possession and quantity of items and the level of education of the head of the family. The total of points was used to classify the individuals into 
one of the following classes: A (high), B and $\mathrm{C}$ (average) and D (low) ${ }^{12}$.

3) The 36-Item Short Form Survey (SF-36), consisting of 36 items in eight dimensions (physical functioning, role limitations due to physical health, pain, general health, vitality, social functioning, role limitations due to emotional problems and mental health). To evaluate the SF-36 survey, scores were attributed to each question, which were subsequently converted into a score ranging from zero to 100 , where zero corresponds to the worst QoL perception and 100 to the best ${ }^{13,14}$.

The tablet versions of the questionnaires were created with Open Data Kit, a free opensource software that offers the ability to design forms and collect data on devices such as smartphones and tablets. The ODK forms were developed in Excel and converted to XML, a standard data format ${ }^{15}$. The tablet device used in the present study was the Android Galaxy Tab 3 with wifi and 7-inch screen. Face-to-face interviews were conducted at the respondents' homes, using the tablets running the ODK app. The study was approved by the Ethics and Research Committee of the Institute of Biosciences of the State University of São Paulo (UNESP), Campus of Rio Claro, with Protocol No. 24154813.4.0000.5465. All participants signed a consent form prior to participation. Ethical principles were respected according to Resolution 466/12 of the National Health Council.

\section{Statistical analysis}

Statistical analysis was performed using Statistical Analysis System (SAS), version 9.2. Descriptive analysis was performed, and its results were presented in absolute numbers and percentages. The Shapiro-Wilk test was performed to verify the distribution of the collected data. Due to the non-normal distribution, the Mann-Whitney U test was used to compare the SF-36 survey data and categorical variables (dis- ease after retirement and retirees who continued working after retirement). The significance level for the statistical tests was 5\% ( $\leq 0.05)$.

\section{Results}

Out of the total sample of 693 participants, 205 were retired and included in subsequent analyses. Briefly, the sample was composed of adults ranging in age from 26 to 95 years. They were mainly men (52.6\%) and married (65.8\%), had elementary schooling $(26.8 \%)$, were of middle class $(47.2 \%)$ and were non-institutionalized (hospitals, long-term institutions - asylums and prisons). Length of service was the most prevalent reason for retirement (66.1\%). The majority of the retirees $(63.3 \%)$ did not reach the minimum recommendation of 150 minutes a week of physical activity (PA), and the average score of Body Mass Index (BMI) was $25.1 \mathrm{~kg} / \mathrm{m}^{2}$. In addition, $38.5 \%$ of retirees continued working after retirement. Most retirees developed some type of illness after retirement (61.9\%). The most prevalent diseases were hypertension $(50.3 \%)$ and depression (37.0\%). (Table 1).

Table 1: Categorical variables on the type of diseases developed after retirement (descriptive analysis)

\begin{tabular}{c|c|c}
\hline $\begin{array}{c}\text { Diseases developed } \\
\text { after retirement }\end{array}$ & $\begin{array}{c}\text { Absolute } \\
\text { (n) }\end{array}$ & $\begin{array}{c}\text { Percentages } \\
\text { (\%) }\end{array}$ \\
\hline Hypertension & 64 & 50.3 \\
\hline Depression & 47 & 37.0 \\
\hline Type II diabetes & 29 & 22.8 \\
\hline Arthritis/arthrosis & 17 & 13.3 \\
\hline Lower back pain & 15 & 11.8 \\
\hline Rheumatism & 11 & 8.6 \\
\hline Embolism/stroke & 11 & 8.6 \\
\hline Heart problems & 9 & 7 \\
\hline Cancer & 8 & 6.2 \\
\hline Osteoporosis & 6 & 4.7 \\
\hline
\end{tabular}

Source: Own authorship, 2016.

Table 2 displays data on the retirees $(n=127)$ who developed a disease after retirement. When 
comparing the QoL scores between retirees who developed a disease after retirement and those who did not, a decline in scores was evident among retirees who developed a disease. Significant scores were observed in physical functioning, pain, general health and vitality.

A comparison of QoL scores between retirees who continued working after retirement and those who did not shows that retirees who did presented higher QoL, with significant differences in physical functioning, general health, and vitality.

\section{Discussion}

This study aimed to evaluate health conditions and QoL of retirees in a medium-sized Brazilian city. The sociodemographic data showed that after retirement most retirees did not continue working $(61.5 \%)$ and that $61.9 \%$ of them developed a disease, hypertension (50.3\%) and depression (37.0\%) being prevalent.

An investigation with regard to the QoL and retirement revealed that there were factors that positively contributed to the QoL of retirees (i.e. standard retirement, working after retirement, regular physical activity and advanced age), and factors that negatively contributed to the QoL (i.e. disability retirement, not working after retirement,
Table 2: Comparison between the SF-36 and the categorical variable (disease after retirement)

\begin{tabular}{|c|c|c|c|c|c|}
\hline SF-36 & $\begin{array}{c}\text { Disease } \\
\text { after } \\
\text { retirement - } \\
\text { Yes }(n=127)\end{array}$ & $\begin{array}{c}\text { Quartiles } \\
(1-3)\end{array}$ & $\begin{array}{c}\text { Disease } \\
\text { after } \\
\text { retirement - } \\
\text { No }(n=78)\end{array}$ & $\begin{array}{c}\text { Quartiles } \\
(1-3)\end{array}$ & p-value * \\
\hline $\begin{array}{l}\text { Physical } \\
\text { functioning }\end{array}$ & 75 & $40-95$ & 90 & $70-100$ & 0.00 \\
\hline $\begin{array}{l}\text { Role limitations } \\
\text { due to physical } \\
\text { health }\end{array}$ & 100 & $0-100$ & 100 & $75-100$ & 0.06 \\
\hline Pain & 62 & $41-100$ & 92 & $61-100$ & 0.00 \\
\hline General health & 72 & $52-87$ & 82 & $72-92$ & 0.00 \\
\hline Vitality & 65 & $45-80$ & 75 & $60-85$ & 0.01 \\
\hline $\begin{array}{c}\text { Social } \\
\text { functioning }\end{array}$ & 100 & $37.5-100$ & 100 & $75-100$ & 0.00 \\
\hline $\begin{array}{c}\text { Role limitations } \\
\text { due to emotional } \\
\text { problems }\end{array}$ & 100 & $100-100$ & 100 & $100-100$ & 0.14 \\
\hline Mental health & 60 & $48-72$ & 68 & $56-72$ & 0.14 \\
\hline
\end{tabular}

Table 3: Comparison between SF-36 and the categorical variable (continued working after retirement)

\begin{tabular}{|c|c|c|c|c|c|}
\hline SF-36 & $\begin{array}{l}\text { Continued } \\
\text { working } \\
\text { after } \\
\text { retirement } \\
\text { Yes }(n=79)\end{array}$ & $\underset{(1-3)}{\text { Quartiles }}$ & $\begin{array}{c}\text { Continued } \\
\text { working } \\
\text { after } \\
\text { retirement } \\
\text { No }(n=126)\end{array}$ & $\begin{array}{c}\text { Quartiles } \\
(1-3)\end{array}$ & p-value \\
\hline $\begin{array}{c}\text { Physical } \\
\text { functioning }\end{array}$ & 90 & $70-95$ & 75 & $45-95$ & 0.00 \\
\hline $\begin{array}{l}\text { Limitations due } \\
\text { to physical health }\end{array}$ & 100 & $25-100$ & 100 & $25-100$ & 0.68 \\
\hline Pain & 72 & $51-100$ & 72 & $51-100$ & 0.87 \\
\hline General health & 80 & $67-92$ & 72 & $57-87$ & 0.03 \\
\hline Vitality & 75 & $60-85$ & 70 & $50-80$ & 0.03 \\
\hline $\begin{array}{c}\text { Social } \\
\text { functioning }\end{array}$ & 100 & $75-100$ & 100 & $50-100$ & 0.10 \\
\hline $\begin{array}{l}\text { Limitations due } \\
\text { to emotional } \\
\text { problems }\end{array}$ & 100 & $100-100$ & 100 & $100-100$ & 0.17 \\
\hline Mental health & 64 & $52-72$ & 64 & $52-72$ & 0.93 \\
\hline
\end{tabular}

depressive symptoms and early retirement). There is evidence that the benefits of continuing to work after retirement may go beyond the physical sphere and include mental aspects ${ }^{16}$. 
The authors investigated the influence of psychological factors on the decision to continue working after retirement and verified the need to feel productive as being the main reason ${ }^{17}$. Our results appear to corroborate the aforementioned findings, as the retirees that did not continue working after retirement had a lower QoL score compared to those who did.

As to the diseases appearing after retirement, hypertension and depression were those observed in our study. Hypertension appears to be present among the elderly after retirement, and this prevalence may be associated with their age and physical inactivity ${ }^{18}$. In addition, the idleness due to lack of work is enough to trigger depressive symptoms, which may become chronic and, if not properly treated, contribute to the development of more profound depressive symptoms ${ }^{19}$. In England, a 21-year longitudinal study verified that the incidence of depression during retirement was mainly due to a socioeconomic factor ${ }^{20}$. Loneliness and depressive symptoms appeared to be related risk factors for worsening cognitive function ${ }^{21}$. In addition, it was observed that an increase in anxiety in late adulthood was associated with age-related losses in both physical and cognitive functioning ${ }^{20}$.

Retirement may be a life-changing moment. It may trigger substantial psychological instability regarding social status and professional relationships, which may be of extreme importance to the course of one's life ${ }^{19,22}$. The authors suggested the importance of considering the retirement transition in the context of life-course influences, especially age, in order to better determine the quality of daily experiences of middle-aged and older adults. In addition, these life-course influences should be considered in retirement planning aimed at enabling adults to navigate the retirement experiences with quality ${ }^{19}$.

The lack of retirement planning and proactive social attitudes may end up demarcating a condition marked by decline in physical and intellectual abilities, triggering depres- sive symptoms post-retirement ${ }^{23}$. In 2009, a longitudinal study among American retirees evidenced that individuals who had discussed retirement with their spouses and had moneysaving plans reported greater welfare in 2004 (controlling for health status, retirement reasons, and income from 1992). These results confirmed the importance of retirement planning and provided a rational basis for the development of measures guided by retirement planning theories ${ }^{20,24}$. Some limitations should be pointed out: information such as the number of medications or the type of work performed after retirement were not considered at the time of data collection. We acknowledge that this information may have had an important role in understanding different variables related to a lack of retirement planning. In addition, such cross-sectional designs do not provide definite information about cause-andeffect relationships.

\section{Conclusion}

The results of this study support the hypothesis that retirees who continued working after retirement have better health conditions and QoL perceptions than the retirees who did not. Retirement may be a phase in which psychosocial diseases seem to be present, allowing the individual to become more vulnerable to additional chronic diseases. Therefore, our study opens paths for future investigations and discussions in order to explore alternative ways to minimize the appearance of psychosocial diseases. Many retirees still do not know how to take advantage of this period ${ }^{25}$. However, it is imperative that those responsible for public health policies pay attention to the need for planning and implementing retirement programs, offering citizens new possibilities for a pleasant and meaningful life, contributing to possible changes in psychological, economic and social spheres. 


\section{References}

1. Brazilian Institute of Geography and Statistics, News Agency. Woman studies more, works more and earns less than men. Rio de Janeiro: IBGE. 2018 [cited 2018 Mar 10]. Available from: https://agenciadenoticias.ibge.gov.br/agencia noticias/2012-agencia-de-noticias/noticias/20234mulher-estuda-mais-trabalha-mais-e ganhamenos-doque-o-homem.html.

2. Veras RP, Oliveira M. Aging in Brazil: the building of a healthcare model. Ciênc. Saúde Colet. 2018 Jun; 23(6):1929-36.

3. Simões CCS, Oliveira LAP. O processo demográfico brasileiro. In: Diretoria de Geociências, Instituto Brasileiro de Geografia e Estatística, organizador. Atlas Nacional do Brasil Milton Santos. Rio de Janeiro: Instituto Brasileiro de Geografia e Estatística; 2010. p. 113-41.

4. Zanelli JC. Processos psicossociais, bem-estar e estresse na aposentadoria. Rev. psicol. organ. trab. 2012 Dec;12(3):329-40.

5. Mazzonna F, Peracchi F. Unhealthy retirement? J. Hum. Resour. 2015 Jul; 52(1):128-51.

6. Cotlear D. Population aging: is Latin America ready? Washington (DC): The World Bank; 2011.

7. Antunes MH. Programas de educação para aposentadoria: como planejar, implementar avaliar. Rev. psicol. organ. trab. 2017 Mar;17(1):71-3.

8. Andrade EIG, Cherchiglia ML, Souza-Junior PRB, Bof de Andrade F, Mambrini JVM, Lima-Costa MF. Fatores associados ao recebimento de aposentadorias entre adultos mais velhos: ELSIBrasil. Rev. saúde pública. 2018 Set;52Supl 2:15s.

9. Sebastião E, Gobbi S, Chodzko-Zajko W, Schwingel A, Papini CB, Nakamura PM, et al. The International Physical Activity Questionnaire-long form overestimates self-reported physical activity of Brazilian adults. Public Health. 2012 Nov;126:967-75.

10. Sebastião E, Chodzko-Zajko W, Schwingel A, Gobbi LTB, Papini CB, Nakamura PM, et al. Perceived barriers to leisure time physical activity: What Brazilians have to say? Open J Prev Med. 2013 Oct;3:491-9.

11. Nakamura PM, Teixeira IP, Smirmaul BPC, Sebastião E, Papini CB, Gobbi S, et al. Health related quality of life is differently associated with leisure-time physical activity intensities according to gender: a cross-sectional approach. Health Qual Life Outcomes. 2014 Aug;12:98.
12. Associação Brasileira de Empresas de Pesquisa (ABEP). Critérios de classificação econômica Brasil. [Internet]. [Cited 2015]: Available from: <www.abep. org/codigosguias/ABEP_CCEB.pdf>.

13. Ware JE, Kosinski M, Gandek B. SF-36 health survey: manual \& interpretation guide. Lincoln, Rhode Island: Quality Metric Inc; 2005. 200 p.

14. Ciconelli RM, Ferraz MB, Santos W, Meinão I, Quaresma MR. Tradução para a língua portuguesa e validação do questionário genérico de avaliação de qualidade de vida SF-36 (Brasil SF-36). Rev. bras. reumatol. 1999 Jun;39(3):143-50.

15. Teixeira, IP, Nakamura, PM, Smirmaul, BPC, Campos, L, Kokubun, E. Data collection using tablets - practical, low-cost and with easy programming. Rev. bras. ativ. fís. saúde. 2018;23:e0014.

16. Pimenta FA, Simil FF, Tôrres HO, Amaral CF, Rezende CF, Coelho TO, et al. Avaliação da qualidade de vida de aposentados com a utilização do questionário SF-36. Rev. Assoc. Med. Bras. 2008 Out;54(1):55-60.

17. Khoury H, Ferreira A, Souza R, Matos A, Barbagelata-Góes S. Por que aposentados retornam ao trabalho? O papel dos fatores psicossociais. Rev. Kairós. 2010 Jun;13(1):147-65.

18. Ernandes G D, Ellen JFS, Franciele NL, Élica CFA , Janine CSA. Characterization of hypertensive and factors hindering the elderly of adhere to the drug treatment of Hypertension. R. Interd. 2015 Set;8(3):39-9.

19. Wong JD, Shobo Y. The moderating influences of retirement transition, age, and gender on daily stressors and psychological distress. Int J Aging Hum Dev. 2017 Nov;85(1):90-117.

20. Tetzner J, Schuth M. Anxiety in late adulthood: Associations with gender, education, and physical and cognitive functioning. Psychol Aging. 2016 Aug;31(5):532-44.

21. Donovan NJ, Wu Q, Rentz DM, Sperling RA, Marshall GA, Glymour MM. Loneliness, depression and cognitive function in older US adults. Int J Geriatr Psychiatry. 2017 May;32(5):564-73.

22. Antunes MH, Moré CL. Família, trabalho e aposentadoria: uma revisão da produção científica no cenário brasileiro. Contextos Clínic. 2014 Dec;7(2):145-54.

23. Grotting MW, Lillebo OS. Health effects of retirement. Working Papers in Economics [Internet]. 2017 Feb [Cited 2018] Available from: <https://ideas. repec.org/p/hhs/bergec/2017_002.html>. 
24. Noone J, Stephens C, Alpass F. Preretirement planning and well-being in later life: a prospective study. J Aging Res. 2009 Jan;31(3):295-317.
25. Denier N, Clouston SA, Richards M, Hofer, SM Retirement and cognition: a life course view. Adv Life Course Res. 2017 Mar;31(1):11-21. 